\title{
Grapevine defoliation by Spodoptera frugiperda Smith, 1797 (Lepidoptera: Noctuidae) in Brazil
}

\section{Orcial Ceolin Bortolotto ${ }^{1^{*}}$ (i) Aline Pomari-Fernandes ${ }^{2}$ Gilberto Rostirolla Batista de Souza ${ }^{3}$ (i)}

${ }^{1}$ Setor de Ciências Agrárias e Tecnologia, Departamento de Fitotecnia e Fitossanidade, Universidade Estadual de Ponta Grossa (UEPG), 84030-900, Ponta Grossa, PR, Brasil. E-mail: bortolotto.orcial@gmail.com. *Corresponding author.

${ }^{2}$ Universidade Federal da Fronteira Sul (UFFS), Laranjeiras do Sul, PR, Brasil.

${ }^{3}$ Ginegar Indústria de Plásticos LTDA, Leme, São Paulo, Brasil.

ABSTRACT: The fall armyworm, Spodoptera frugiperda Smith, 1797 (Lepidoptera: Noctuidae), is a polyphagous pest that causes losses in several crops. The knowledge of host plants is essential for establishing management and control strategies. The present study reported the first occurrence of S. frugiperda in Brazilian grapevines. It is recommended that further studies should be carried out in the laboratory to understand the biological aspects of the damage to different structures (leaves and grapes). This information will be essential to assess the potential of $S$. frugiperda damage to vines.

Key words: lepidopterans, Vitis vinifera, fruit pests, Fall armyworm.

Spodoptera frugiperda Smith, 1797 (Lepidoptera: Noctuidae) desfolhando videira no Brasil

RESUMO: A lagarta-do-cartucho Spodoptera frugiperda Smith, 1797 (Lepidoptera: Noctuidae) é uma praga polifaga que ocasiona danos em diversos cultivos, e o conhecimento do seu espectro de hospedeiros é essencial para o estabelecimento de estratégias de manejo e controle. Assim, o presente estudo registra pela primeira vez a ocorrência de S. frugiperda em videiras brasileiras. Desse modo, recomenda-se a realização de estudos adicionais em laboratório para compreender os aspectos biológicos e os danos as diferentes estruturas (vegetativas e uvas). Essa informação será essencial para avaliar o potencial de dano de S. frugiperda se alimentando de videiras.

Palavras-chave: lepidópteros, Vitis vinifera, pragas de frutiferas, lagarta-do-cartucho.

The grapevine, Vitis vinifera (Vitaceae), is a major plantation species worldwide. Currently, global grapevine production is approximately 77.8 million t over 7.4 million ha (OIV, 2020), and Europe and Asia are responsible for approximately $50 \%$ of this production (OIV, 2020). In Brazil, production is $\sim 1.5$ million $\mathrm{t}$ in an area of 0.757 million ha (BRAZILIAN YEARBOOK, 2020). However, biotic factors, such as pathogens (BOIS et al., 2017) and arthropod pests (REINEKE \&THIERY, 2016) are predominant in limiting grapevine production.

A diverse range of arthropod pest species can damage grapevines by affecting the root system, stem, leaves, and fruit (FORMOLO et al., 2011; REINEKE \& THIERY, 2016; WEIBINGER et al., 2019; RODRIGUEZ-GONZALEZ et al., 2020). Among the arthropod pests of aerial plant parts, the lepidopterans are a major cause of damage to leaves and grapes (ZENKER et al., 2010; BORTOLI et al., 2012;
VENTURA et al., 2015). Thus, to establish efficient control strategies, knowledge of the lepidopteran species that damage cultivated plants is essential.

Spodoptera frugiperda Smith, 1797 (Lepidoptera: Noctuidae) is recognized as a major global agricultural pest, as it is highly polyphagous (CASMUZ et al., 2010; MONTEZANO et al., 2018) and can damage approximately 353 host species (MONTEZANO et al., 2018). In Brazil, $S$. frugiperda has been recognized as an important cause of damage, mainly in corn crops, since the 1950s (LEIDERMAN \& SAUER, 1953). However, studies indicated that it has been present in Brazilian fields since approximately 1920 (LEIDERMAN \& SAUER, 1953).

Although, fall armyworms feed preferentially on Poaceae (CASMUZ et al., 2010; MONTEZANO et al., 2018), they can also feed on other species including soybeans, beans, and 
cotton (MONTEZANO et al., 2018). However, to date, Spodoptera eridania Stoll, 1872 (Lepidoptera: Noctuidae) is the only species belonging to the Spodoptera complex reported to damage the fruit and leaves of grapevines in Brazil (BORTOLI et al., 2012). The present study is the first to record the occurrence of $S$. frugiperda damaging grapevines in Brazil.

The study was carried out in a commercial seedling nursery (Figure 1) at Petrolina (9²3'39" South, 40³0'35" West), Bahia, Brazil. The infested seedlings (Figure 2) belonged to the "early" Isabel variety (ISACL 1) and were grafted on the material,
IAC 572 Jales (Vitaceae) [resulting from the crossing of 101-14 MGT (Vitis riparia $\times$ Vitis rupestris) $\times$ Vitis caribaea], to confer resistance to phylloxera and nematodes. Visual inspection was performed to consider leaf injuries (Figure 3) associated with $S$. frugiperda larvae feeding. The larvae $(n=20$ individuals) were collected on December 5, 2020, placed in flasks with $70 \%$ alcohol, and sent to the Entomology Laboratory of the State University of Ponta Grossa (UEPG) for identification by the first author.

To date, this is the first record of $S$. frugiperda feeding on grapevines in Brazilian fields.

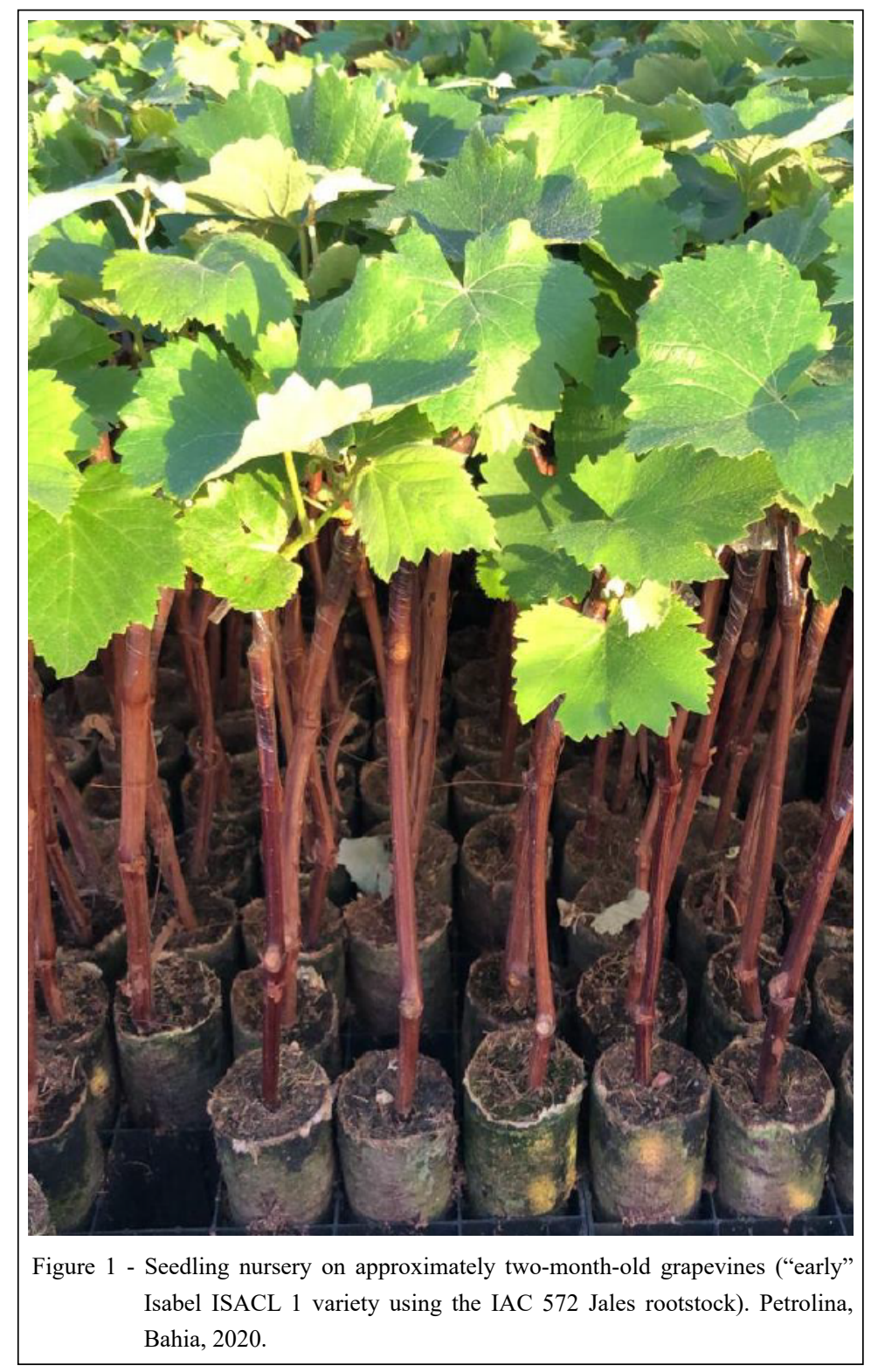

Ciência Rural, v.52, n.7, 2022. 


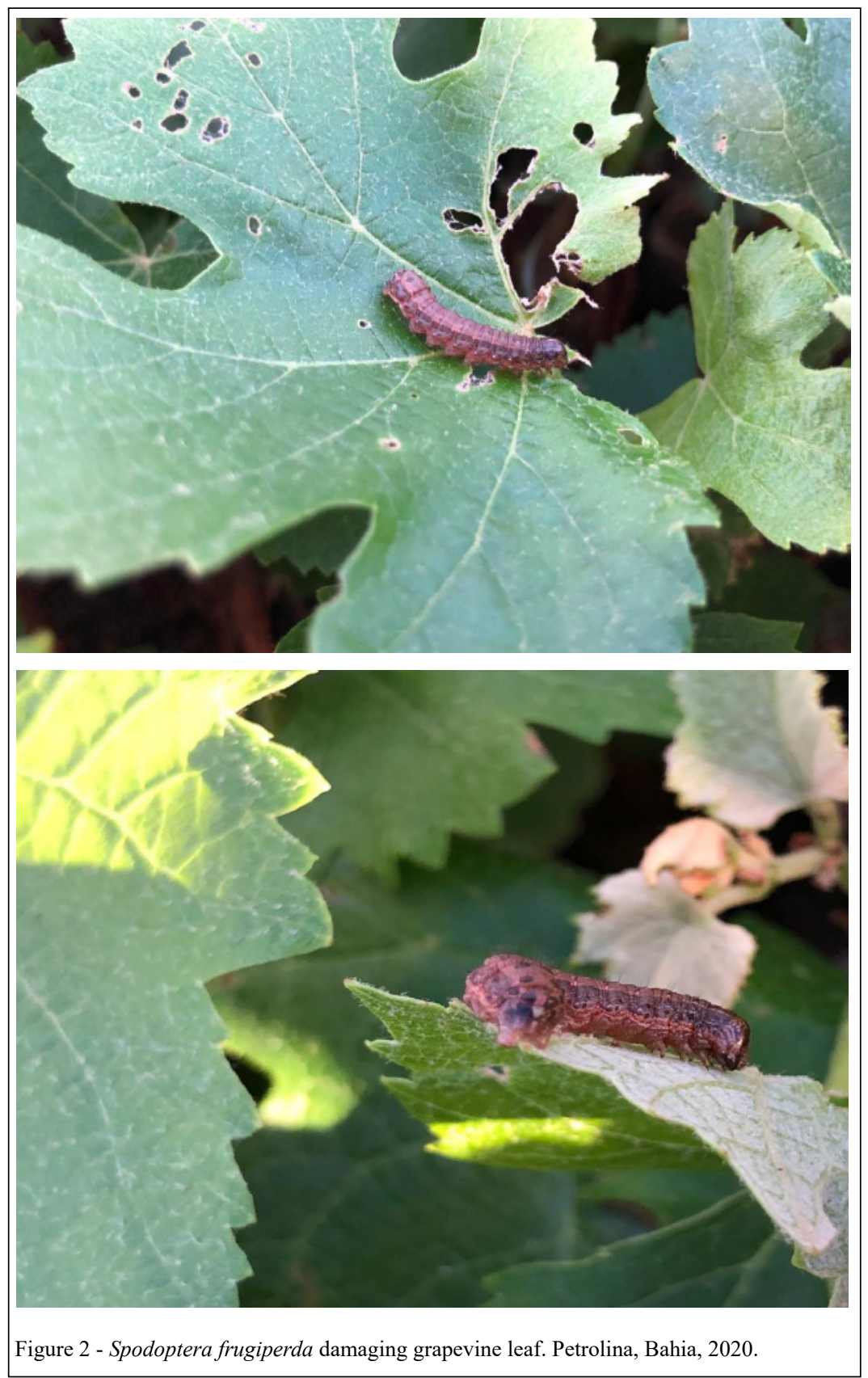

Although, not quantified in the field, leaf injury was $1020 \%$, which damaged the plants. The pest infestation required intervention by the producer, including three sequential insecticide applications, with a mixture of two insecticides, i.e., Chlorantraniliprole (150 $\left.\mathrm{mL} \cdot \mathrm{ha}^{-1}\right)$ and lambda-Cyhalothrin $\left(30 \mathrm{~mL} \cdot \mathrm{ha}^{-1}\right)$. After the applications, no re-infestation was observed. It is important to point out that the seedling production area in the study is located close to a disposal area for plant residues from other vinifera varieties. This observation allows us to infer that the occurrence and spread of the pest has a greater amplitude, suggesting that this pest may have greater importance in a short period of time.

Previous reports of the occurrence of this species in vines were restricted to other countries

Ciência Rural, v.52, n.7, 2022. 


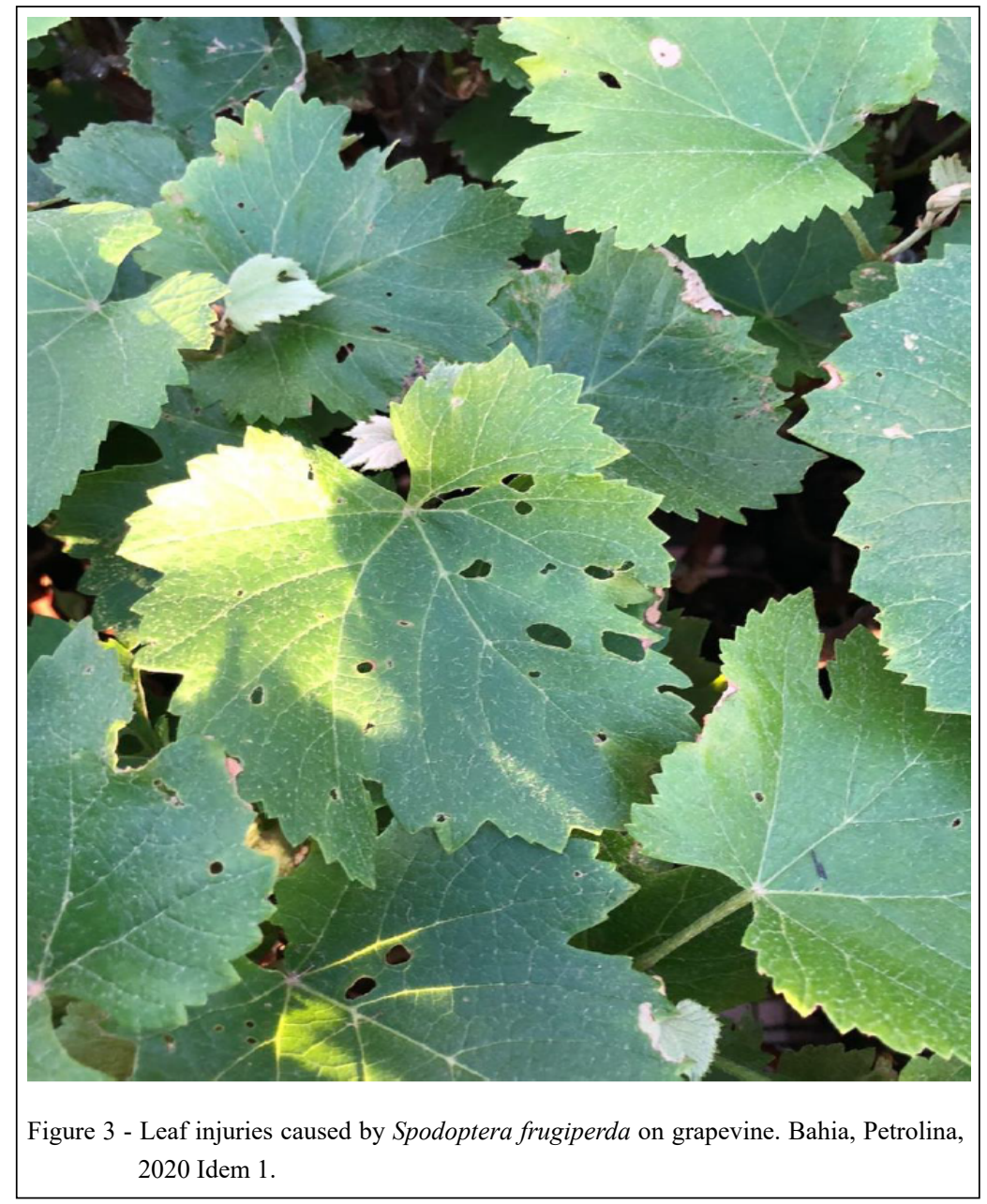

such as Chile, Venezuela, and the United States (CASMUZ et al., 2010; MONTEZANO et al., 2018). Interestingly; although, the fall armyworm has been mentioned as damaging grapevines in these countries, there are no descriptions to clearly evidence this, suggesting that these previous mentions may have been field observations rather than scientific reports.

Among Spodoptera species, S. eridania larvae have been observed to damage grapevine fruit and leaves in Brazil (BORTOLI et al., 2012); although, only in vitro. In addition, BORTOLI et al. (2012) observed that leaf consumption improved the performance of $S$. eridania, reduced the life cycle (compared to that of $S$. eridania that fed on strawberry plants), and did not compromise female fertility. These findings suggest that grapevine leaves have an adequate nutritional composition for $S$. eridania and indicate the potential of this species to cause damage to the crop. Further studies are needed to investigate the development of $S$. frugiperda on grapevine fruit and leaves, because its biological performance is strongly influenced by the host quality (SILVA et al., 2017). Knowledge of the plant-insect relationship is important as it will the aid the inference of the harmful potential of the species.

Finally, our findings indicate the importance of monitoring the occurrence and population fluctuations of $S$. frugiperda in grapevine fields. Additionally, complementary studies are needed to understand the behavior of this pest better when feeding on the vegetative and reproductive structures of a grapevine. Future research should evaluate the consumption capacity, food preference (varieties), and damage capacity (leaves and fruit) of $S$. frugiperda on grapevines.

Ciência Rural, v.52, n.7, 2022. 
DECLARATION OF CONFLICT OF INTEREST

The authors declare no conflict of interest.

\section{ACKNOWLEDGEMENTS}

To Coordenação de Aperfeiçoamento de Pessoal de Nível Superior (CAPES) and Conselho Nacional de Desenvolvimento Científico e Tecnológico $(\mathrm{CNPq})$ for financial support. The authors declare there to be no conflict of interest in carrying out or publishing this work.

\section{AUTHORS' CONTRIBUTIONS}

The authors contributed equally to the manuscript.

\section{REFERENCES}

BRAZILIAN HORTI \& FRUIT YEARBOOK 2020. Gazeta Santa Cruz, Santa Cruz do Sul, pp.96. 2019.

BOIS, B. et al. Climate vs grapevine pests and diseases worldwide: The first results of a global survey. OENO One, v.51, p.133-139, 2017. Available from: <https://oeno-one.eu/article/view/1780>. Acessed: Jan. 20, 2021. doi: <https://doi.org/10.20870/oenoone.2017.51.2.1780>.

CASMUZ, A. et al. Revisión de los hospederos del gusano cogollero del maíz, Spodoptera frugiperda (Lepidoptera: Noctuidae). Revista de la Sociedad Entomológica Argentina, v. 69, p. 209-231, 2010. Available from: <https://www.redalyc.org/ articulo.oa?id=322028487010>. Acessed: Jan. 22, 2021 .

BORTOLI, L.C. et al. Biologia e tabela de vida de fertilidade de Spodoptera eridania (Cramer) (Lepidoptera: Noctuidae) em morangueiro e videira. Revista Brasileira de Fruticultura, v.34, p.1068-1073, 2012. Available from: <https://www.scielo. br/j/rbf/a/ZWSCQdCVZj5pxczNz9YPHdj/abstract/?lang=pt $>$ Acessed: Feb. 23, 2021. doi: <https://doi.org/10.1590/S0100$29452012000400013>$.

FORMOLO, R. et al. Diagnóstico da área cultivada com uva fina de mesa (Vitis vinifera L.) sob cobertura plástica e do manejo de pragas. Revista Brasileira de Fruticultura, v.33, p.103-110, 2011. Available from: <https://pdfs semanticscholar.org/ff5b/6a895ae90fe492df672de07eda 1 e2 c319e3f.pdf? ga=2.168063777.1232064353.16312929151813769795.1621966170>. Acessed: Feb. 13, 2021. doi: <https:// doi.org/10.1590/S0100-29452011005000047>.
LEIDERMAN, L.; SAUER, H.F.G. A lagarta dos milharais Laphygma frugiperda (Abbot e Smith, 1797). O Biológico, v.19, p.105-113, 1953.

MONTEZANO, D.G. et al. Host plants of Spodoptera frugiperda (Lepidoptera: Noctuidae) in the Americas. African Entomology, v.26, p.286-300, 2018. Available from: <https://bioone.org/ journals/african-entomology/volume-26/issue-2/003.026.0286/ Host-Plants-of-Spodoptera-frugiperda-Lepidoptera--Noctuidaein-the/10.4001/003.026.0286.full $>$. Acessed: Feb. 15, 2021. doi: $<$ https://doi.org/10.4001/003.026.0286>.

REINEKE, A., THIÉRY, D. Grapevine insect pests and their natural enemies in the age of global warming. Journal of Pest Science, v.89, p.313-328, 2016. Available from: <https://link.springer.com/ article/10.1007/s10340-016-0761-8>. Acessed: Feb. 22, 2021. doi: $<$ https://doi.org/10.1007/s10340-016-0761-8>.

RODRÍGUEZ-GONZÁLEZ, A., et al. Failure under stress of grapevine wood: The effects of the cerambycid Xylotrechus arvicola on the biomechanics properties of Vitis vinifera. Maderas. Ciencia y tecnologia, v.22, p.167-178, 2020. Avaiblable from: $<$ https:// scielo.conicyt.cl/scielo.php?script $=$ sci_arttext\&pid $=$ S0718221X2020000200167>. Acessed: Jan. 22, 2021. doi: <http:// dx.doi.org/10.4067/S0718-221X2020005000203>.

SILVA, D.M. et al. Biology and nutrition of Spodoptera frugiperda (Lepidoptera: Noctuidae) fed on different food sources. Scientia Agricola, v.74, p.18-31, 2017. Available from: $<$ https://www.scielo.br/j/sa/a/SLwN4VQh8Vmtb8mK9qrSRDR/ abstract/?lang=en $>$. Acessed: Mar. 10, 2021. doi: <https://doi. org/10.1590/1678-992x-2015-0160>.

VENTURA, M.U. et al. First record of Heliothis virescens (Lepidoptera: Noctuidae) damaging table grape bunches. Florida Entomology, v.98, p.783-786, 2015. Available from: $<$ https://bioone.org/journals/florida-entomologist/volume-98/ issue-2/024.098.0259/First-Record-of-Heliothis-virescensLepidoptera--Noctuidae-Damaging-Table/10.1653/024.098.0259. full $>$. Acessed: Mar. 3, 2021. doi: <https://doi org/10.1653/024.098.0259>.

WEIBINGER, L. et al. Effects of variety and grape berry condition of Vitis vinifera on preference behavior and performance of Drosophila suzukii. Insects, v.10, p.1-15, 2019. Available from: $<$ https://pubmed.ncbi.nlm.nih.gov/31801222/>. Acessed: Jan. 10, 2021. doi: <https://doi.org/10.3390/insects10120432>.

ZENKER, M.M. et al. Noctuidae moths occurring in grape orchards in Serra Gaúcha, Brazil and their relation to fruit-piercing. Revista Brasileira de Entomologia, v.54, p.288-297., 2010. Available from: $<$ https://www.scielo.br/j/rbent/a/c9gThb9b38BtWzfD7NK7 5Jf/?lang=en $>$. Available from: Feb. 12, 2021. doi: <https://doi. org/10.1590/S0085-56262010000200012>. 